\title{
Denitrovibrio acetiphilus, a novel genus and species of dissimilatory nitrate-reducing bacterium isolated from an oil reservoir model column
}

\author{
Siri Myhr and Terje Torsvik
}

Author for correspondence: Siri Myhr. Tel: +47 55584638. Fax: +47 55589671. e-mail: siri.myhr@im.uib.no

Department of Microbiology, University of Bergen, Jahnebakken 5, PO Box 7800, N-5020

Bergen, Norway

\begin{abstract}
A novel dissimilatory, nitrate-reducing bacterium, designated strain $\mathrm{N2460}^{\top}$, was isolated from an oil reservoir model column. Strain $\mathrm{N}^{2460^{\top}}$ is a mesophilic, obligately anaerobic, marine, Gram-negative bacterium. The cells are vibrioshaped and motile by a bipolar flagellum. Strain $\mathrm{N2460}^{\top}$ reduces nitrate to ammonia in a mineral medium supplied by acetate. The presence of a 2oxoglutarate dehydrogenase activity indicates that acetate is oxidized via the citric acid cycle. No growth is obtained on formate, higher fatty acids, malate, fumarate, benzoate, alcohols, sugar, yeast extract, crude oil, alkanes, proline, hydrogen, sulfur or thiosulfate with nitrate as electron acceptor. Oxygen, sulfate, thiosulfate and sulfur are not utilized as alternative electron acceptors. Strain ${\mathrm{N} 2460^{\top}}^{\top}$ grows fermentatively on fumarate, but not on pyruvate. The $G+C$ content of the DNA is $42.6 \mathrm{~mol} \%$. 165 rRNA gene analysis shows that strain $\mathrm{N}^{2460^{\circ}}$ belongs to the Bacteria and that the closest relative is 'Geovibrio ferrireducens' (sequence similarity 86.9\%). On the basis of phylogenetic as well as phenotypic data, it is proposed that strain $\mathrm{N}^{2460^{\top}}$ represents the type strain of a new genus and species, Denitrovibrio acetiphilus gen. nov., sp. nov.
\end{abstract}

Keywords: Denitrovibrio acetiphilus, nitrate-reducing bacterium, oil reservoir model column

\section{INTRODUCTION}

Reservoir souring, the production of $\mathrm{H}_{2} \mathrm{~S}$ in oil wells by sulfate-reducing bacteria (SRB), is a detrimental process of great concern to the oil industry (Hamilton, 1985; Herbert, 1987; Beeder, 1996). Addition of nitrate to the injection water may reduce $\mathrm{H}_{2} \mathrm{~S}$ production by stimulating a competing group of anaerobic bacteria, the nitrate-reducing bacteria (NRB) (Reinsel et al., 1996). In order to investigate the potential of nitrate as an inhibitor of reservoir souring, an oil reservoir model column was constructed (S. Myhr, B.-L. P. Lillebø, E. Sunde, J. Beeder and T. Torsvik, unpublished results). The model column consisted of a sand-packed Perspex tube with crude oil as the sole carbon and energy source. The column was inoculated with a broad

Abbreviations: NRB, nitrate-reducing bacteria; SRB, sulfate-reducing bacteria

The GenBank accession number for the $16 \mathrm{~S}$ rDNA sequence of strain $\mathrm{N}^{2460}{ }^{\top}$ is AF146526. spectrum of bacteria, including aerobic oil-degrading bacteria, NRB, SRB and methanogens. The system was flooded continuously with synthetic seawater medium. When stable $\mathrm{H}_{2} \mathrm{~S}$ production was established, nitrate was added to the medium. During nitrate injection, several NRB were enriched and isolated from the column. In this paper, we describe one of these isolates, strain $\mathrm{N} 2460^{\mathrm{T}}$, which is an obligately anaerobic acetate specialist. It represents a new genus on the recently described phylogenetic line of 'Flexistipes sinusarabici' (Fiala et al., 1990), 'Geovibrio ferrireducens' (Caccavo et al., 1996) and Deferribacter thermophilus (Greene et al., 1997).

\section{METHODS}

Source of organism. Strain $\mathrm{N} 2460^{\mathrm{T}}$ was isolated from an oil reservoir model column (S. Myhr, B.-L. P. Lillebø, E. Sunde, $\mathrm{J}$. Beeder and T. Torsvik, unpublished results). The column consisted of a Perspex tube $(9 \times 192 \mathrm{~cm})$ packed with finegrained sand, saturated with crude oil and flooded with 


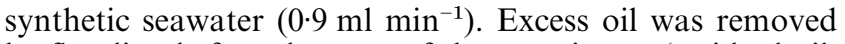
by flooding before the start of the experiment (residual oil, $0 \cdot 651)$. The pore volume was $2 \cdot 71$.

The column was inoculated with enrichment cultures of aerobic oil-degrading bacteria, NRB, SRB and methanogens (enriched at $30^{\circ} \mathrm{C}$ ). Aerobic oil-degrading bacteria were enriched from two reverse-flooded water injectors (B02 and B26) at the Statfjord oilfield (North Sea) and a biological treatment plant for oil-polluted water (OMV oil refinery, Vienna, Austria). NRB were enriched from a nitrate bioreactor for removal of $\mathrm{H}_{2} \mathrm{~S}$ from ballast water (Sture oil terminal, Norway). A mixed culture of SRB and methanogens was collected from two model columns constructed in a previous experiment designed to investigate microbial $\mathrm{H}_{2} \mathrm{~S}$ production and methanogenesis at low sulfate concentrations (K. Drønen and T. Torsvik, unpublished). These columns were initially inoculated with the following bacteria: SRB and methanogens enriched from produced water (Statfjord oilfield, North Sea), ballast/process water from a biological treatment plant (Mongstad oil refinery, Norway) and a freshwater lake sediment (Tveitevatnet, Bergen, Norway); Clostridium propionicum DSM 1682 ${ }^{\mathrm{T}}$; Desulfobacter vibrioformis B54 ${ }^{\mathrm{T}}$ (DSM 8776 ${ }^{\mathrm{T}}$ ); two SRB strains isolated from the injection water systems at the Gullfaks B and Statfjord B oil platforms (North Sea); Methanosarcina barkeri DSM $800^{\mathrm{T}}$; and Methanococcus vannielii DSM $1224^{\mathrm{T}}$.

The oil reservoir model column was first inoculated with enrichment cultures of oil-degrading bacteria to consume oxygen in the column. Subsequently, SRB and methanogens were added. After establishing an SRB biofilm and stable $\mathrm{H}_{2} \mathrm{~S}$ production, the column was inoculated with NRB and $0.5 \mathrm{mM} \mathrm{NaNO}_{3}$ was added to the synthetic seawater. The experiment was run at a low room temperature $\left(17-20^{\circ} \mathrm{C}\right)$.

Enrichment and isolation. NRB enrichments from the model column were initiated after $14 \mathrm{~d}$ with nitrate injection. NRB were enriched in an anoxic, reduced, marine mineral medium (NRB medium) containing the following components $\left(1^{-1}\right)$ : $0.02 \mathrm{~g} \mathrm{Na}_{2} \mathrm{SO}_{4}, 1.0 \mathrm{~g} \mathrm{KH}_{2} \mathrm{PO}_{4}, 0.25 \mathrm{~g} \mathrm{NH}_{4} \mathrm{Cl}, 20.0 \mathrm{~g} \mathrm{NaCl}$, $3.0 \mathrm{~g} \mathrm{MgCl}{ }_{2} .6 \mathrm{H}_{2} \mathrm{O}, 0.5 \mathrm{~g} \mathrm{KCl}, 0 \cdot 15 \mathrm{~g} \mathrm{CaCl}_{2} .2 \mathrm{H}_{2} \mathrm{O}, 0.7 \mathrm{~g}$ $\mathrm{NaNO}_{3}, 1 \mathrm{ml}$ trace element solution SL10 (Widdel et al., 1983 ) and $0.5 \mathrm{ml} 0.2 \%$ resazurin. After autoclaving in a dispenser, the medium was cooled under nitrogen gas. Five $\mathrm{ml}$ vitamin solution (Pfennig, 1978), $30 \mathrm{ml} 1 \mathrm{M}$ $\mathrm{NaHCO}_{3}$ and $4 \mathrm{ml} 0.5 \mathrm{M} \mathrm{Na} \mathrm{S}_{2} \mathrm{~S}$ were added aseptically and the $\mathrm{pH}$ was adjusted to $6 \cdot 8-7 \cdot 2$ with $\mathrm{HCl} / \mathrm{Na}_{2} \mathrm{CO}_{3}$. Finally, the medium was dispensed into nitrogen-flushed $50 \mathrm{ml}$ serum bottles or $20 \mathrm{ml}$ tubes and sealed by butyl rubber stoppers and aluminium crimp seals. Acetate $(20 \mathrm{mM}$ final concentration) was added from a sterile, anoxic stock solution prior to inoculation. A $2 \mathrm{ml}$ inoculum of sand/water/oil (mixed from oxic and anoxic zones in the column) was added to $20 \mathrm{ml}$ medium and incubated at $30^{\circ} \mathrm{C}$. A pure culture was obtained by the agar shake dilution method (Ljungdahl \& Wiegel, 1986). The method involved a serial dilution of the enrichment culture in $45^{\circ} \mathrm{C}$ medium containing $1.0 \%$ agarose (w/v) (washed five times with distilled water). The solidified tubes were incubated at $30^{\circ} \mathrm{C}$. Several colonies were picked and transferred to growth medium. All colonies examined consisted of similar vibrioid bacteria. To ensure that a pure culture was obtained, agar dilution was repeated twice for one of the colonies/cultures.

Physiological studies. Strain N2460 ${ }^{\mathrm{T}}$ was tested for its ability to use different electron donors and acceptors. An increase in cell number $/ \mathrm{OD}_{600}$ in three successive transfers $(10 \%$ inoculum, $v / v$ ) was used as the criterion for growth. Electron donors were added to NRB medium from sterile, anoxic stock solutions, unless otherwise stated. The following final concentrations were applied: $20 \mathrm{mM}$ acetate and lactate; $10 \mathrm{mM}$ formate, propionate, butyrate, valerate, caproate, palmitate, malate and thiosulfate; $4 \mathrm{mM}$ benzoate and fumarate; $0 \cdot 1 \%$ methanol, ethanol, glucose, fructose, yeast extract, crude oil and 'alkane mixture' [equal amounts of heptane, octane, decane and dodecane; pristane $(10 \%, \mathrm{v} / \mathrm{v})$ added as internal standard]; $5 \mathrm{mM}$ phenylacetate and heptanoate; $2.5 \mathrm{mM}$ octanoate; $1.25 \mathrm{mM}$ nonanoate and decanoate; $0.5 \mathrm{mM}$ undecanoate; $1 \mathrm{mM}$ proline. Hydrogen was added as an $80 \% \quad \mathrm{H}_{2} / 20 \% \quad \mathrm{CO}_{2}$ headspace and elemental sulfur was added as a small amount of sterile powder. Different electron acceptors were added from sterile, anoxic stock solutions (except for sulfur) to medium with $20 \mathrm{mM}$ acetate and no nitrate. The following final concentrations were used: $30 \mathrm{mM}$ sulfate, $10 \mathrm{mM}$ thiosulfate and ferric iron (ferric pyrophosphate) and $0 \cdot 2 \mathrm{mM}$ oxygen (air saturation). Sulfur was added as a small amount of sterile powder. Fermentative growth was tested in medium without nitrate, containing $10 \mathrm{mM}$ pyruvate and $4 \mathrm{mM}$ fumarate. Temperature, $\mathrm{pH}$ and salinity spectra for growth were determined in medium with $20 \mathrm{mM}$ acetate and $8 \mathrm{mM}$ nitrate. Except for the temperature experiment, all incubations were performed at $30^{\circ} \mathrm{C}$.

Chemical measurements. Nitrite was measured by a nitrite test tube (Hach). Ammonia was measured by the modified phenol/hypochlorite method (Solorzano, 1969).

Morphology. Cell morphology was examined by phasecontrast microscopy (Labolux K; Leitz) and transmission electron microscopy (TEM) (JEOL 100 CX $80 \mathrm{kV}$ electron microscope). For TEM, cells were stained negatively with $1.5 \%(\mathrm{w} / \mathrm{v})$ uranyl acetate in methanol on Formvar-coated grids. Gram-typing was performed by the $\mathrm{KOH}$ method described by Buck (1982).

Enzyme assays. Cells from 21 of a culture of strain N2460 (grown to late exponential/early stationary phase) were harvested by centrifugation $\left(8000 \mathrm{~g}\right.$ for $20 \mathrm{~min}$ at $4{ }^{\circ} \mathrm{C}$ ) and washed once in medium without substrate. The cell pellet $(450 \mathrm{mg})$ was resuspended in $3 \mathrm{ml}$ anoxic $0 \cdot 1 \mathrm{M}$ Tris $/ \mathrm{HCl}$ buffer, $\mathrm{pH} 8 \cdot 1$. Cells were disrupted by sonication $(2 \times 30 \mathrm{~s}$ on ice) (Sonicel Disrupter; Du Pont Research). Cell debris and metal sulfides were removed by centrifugation $(21000 \mathrm{~g}$ for $20 \mathrm{~min}$ at $4{ }^{\circ} \mathrm{C}$ ). The supernatant (cell extract) was transferred immediately to an anoxic serum bottle and flushed for $10 \mathrm{~min}$ with argon. The cell extract was stored on ice and assayed photometrically within an hour for activity of carbon-monoxide dehydrogenase and 2-oxoglutarate dehydrogenase, using the methods described by Beeder et al. (1994) and Zeikus et al. (1977). The assays were performed at room temperature. Proteins were measured according to Bradford (1976).

Phospholipid fatty acids. The composition of phospholipid fatty acids was analysed by the method described by Frostegård et al. (1993), modified by Odden (1998). The analysis was performed by $\mathrm{M}$. Galteland and E. Odden (Norsk Hydro Research Centre, Porsgrunn, Norway).

DNA base composition. DNA was isolated by cell disruption in a French pressure cell and purification on hydroxyapatite according to the procedure of Cashion et al. (1977). The $\mathrm{G}+\mathrm{C}$ content was determined by HPLC analysis as de- 
scribed by Mesbah et al. (1989) using non-methylated lambda DNA as a standard. The analysis was performed by U. Mendrock (DSMZ).

16S rDNA sequencing and phylogenetic analysis. Extraction of genomic DNA, PCR-mediated amplification of the 16S rDNA and purification of the PCR products were carried out as described previously (Rainey et al., 1996). Purified PCR products were sequenced using the ABI PRISM Dye Terminator cycle sequencing ready reaction kit (Applied Biosystems) as directed in the manufacturer's protocol. Sequence reactions were electrophoresed using the Applied Biosystems 373A DNA sequencer. The resulting sequence data were put into the alignment editor ae2 (Maidak et al., 1996), aligned manually and compared with representative 16S rRNA gene sequences of organisms belonging to the domain Bacteria (Maidak et al., 1996). For comparison, 16S rRNA sequences were obtained from the EMBL database or RDP (Maidak et al., 1996). The 16S rRNA gene similarity values were calculated by pairwise comparison of the sequences within the alignment. For construction of the phylogenetic dendrogram, operations of the PHYLIP package (Felsenstein, 1993) were used: (i) pairwise evolutionary distances were computed from percentage similarities by the correction of Jukes \& Cantor (1969); and (ii) on the basis of the evolutionary distance values, a phylogenetic tree was constructed by the neighbour-joining method (Saitou \& Nei, 1987). The root of the tree was determined by including the $16 \mathrm{~S}$ rRNA gene sequence of Aquifex pyrophilus in the analysis. The 16S rDNA analysis was performed by $\mathrm{C}$. Spröer (DSMZ).

Polyclonal antibodies. A polyclonal antiserum against strain $\mathrm{N} 2460^{\mathrm{T}}$ was prepared by the method described by Christensen et al. (1992), with minor modifications (Beeder et al., 1994). The titre and specificity of the serum were determined by the fluorescent antibody (FA)-DAPI doublestaining technique (Hoff, 1988), performed on multi-well glass slides. A selection of other NRB and SRB isolates from the model column (N2461, N2660, S2550, S2450 and S2650) served as negative controls. Twenty $\mu$ l samples of bacterial cultures (grown to late exponential phase) were applied to the slides and air-dried. Salt precipitates were carefully washed away with sterile-filtered distilled water. Fifty $\mu l$ PBS-diluted antiserum was added to the wells. The slides were incubated in a moist chamber for $20 \mathrm{~min}$ to allow antibody binding. The antibody solution was then washed away with sterile-filtered distilled water and FITC-conjugated secondary antibodies (goat anti-rabbit $\mathrm{IgG}$ ), diluted $1: 40$ in PBS, were added. The slides were incubated for $20 \mathrm{~min}$ in the moist chamber, protected from light. Finally, the conjugate solution was washed away and the bacteria were stained with DAPI (10 $\mu \mathrm{g} \mathrm{ml}^{-1}$ in sterile distilled water) for $2 \mathrm{~min}$, washed and air-dried. The preparations were viewed with an epifluorescence microscope (Microphot; Nikon) with separate filters for FITC and DAPI signals. Only bacteria showing a clear halo with the FITC filter package and a blue signal with the DAPI filter package were regarded as positive.

Construction of oligonucleotide probe. Several potential probe sequences against the $\mathrm{V} 3$ region of the strain $\mathrm{N} 2460^{\mathrm{T}}$ $16 \mathrm{~S}$ rRNA gene were tested theoretically using the PROBE MATCH program (Ribosomal Database Project II; http://www.cme.msu.edu/rdp). For the probe N2460A (sequence: 5'-GAACCATTTCTTCCCTGCTG), no matches were found in the database. This probe was synthesized with a CY3 fluorochrome in the $5^{\prime}$ end (Interactiva Biotechnologie) and tested empirically in whole-cell hybri- dization on multi-well glass slides, by the method described by Amann (1995). According to the PROBE MATCH search results, all known bacterial sequences have at least three mismatches compared with the probe. One of the strains showing three mismatches, Desulfonatronovibrio hydrogenovorans (DSM 9292), served as a negative control together with the following NRB and SRB strains from the model column: N2660, S2251, S2250, S2450, S2550, S2551, S2650 and $\mathrm{S} 2651$

\section{RESULTS}

\section{Enrichment and isolation}

A rapidly moving vibrioid bacterium was observed in the enrichment bottle $2 \mathrm{~d}$ after inoculation. A dense culture was obtained after $5 \mathrm{~d}$, consisting almost exclusively of the vibrio. Colonies that appeared in the agar tubes were off-white and diffuse. No gas production was detected. A strain designated $\mathrm{N} 2460^{\mathrm{T}}$ was isolated in pure culture.

\section{Physiological studies}

The isolated strain, $\mathrm{N} 2460^{\mathrm{T}}$, grew well on acetate with nitrate as electron acceptor, producing ammonia (nitrite was detected as an intermediate). The shortest doubling time at $35^{\circ} \mathrm{C}$ was about $8 \mathrm{~h}$. No growth was detected with the following electron donors: formate, lactate, propionate, butyrate, valerate, caproate, heptanoate, octanoate, nonanoate, decanoate, undecanoate, palmitate, malate, fumarate, benzoate, phenylacetate, methanol, ethanol, glucose, fructose, yeast extract, crude oil, alkanes $\left(\mathrm{C}_{7}, \mathrm{C}_{8}, \mathrm{C}_{10}\right.$ and $\left.\mathrm{C}_{12}\right)$, proline, hydrogen, sulfur and thiosulfate. Sulfate, thiosulfate, sulfur and oxygen were not utilized as alternative electron acceptors. Oxygen inhibited growth of strain $\mathrm{N} 2460^{\mathrm{T}}$ and the strain was unable to grow in a non-reduced anoxic medium. This constituted a problem when testing ferric iron as electron acceptor: ferric pyrophosphate reacted chemically with sulfide in the medium, raising the redox potential and leading to inhibition of growth of the bacterium. It was therefore not possible to test iron reduction in a batch culture. Strain N2460 ${ }^{T}$ grew fermentatively on fumarate, while no growth was detected on pyruvate in medium without nitrate. Vitamins were required for growth.

Strain $\mathrm{N} 2460^{\mathrm{T}}$ grew at temperatures between 4 and $40^{\circ} \mathrm{C}$ with an optimum at $35-37^{\circ} \mathrm{C}$. No growth was obtained at $45^{\circ} \mathrm{C}$. $\mathrm{NaCl}$ was not required for growth and strain $\mathrm{N} 2460^{\mathrm{T}}$ grew well in medium containing up to $6 \% \mathrm{NaCl}(\mathrm{w} / \mathrm{v})$ (optimum at $2-4 \%$ ). Growth occurred between pH 6.5 and 8.6. No growth was observed at $\mathrm{pH} 6 \cdot 2$ or 8.9 .

\section{Morphology}

As seen by phase-contrast microscopy, cells of strain $\mathrm{N} 2460^{\mathrm{T}}$ were vibrio-shaped, measuring $0.5-0.7 \times 1 \cdot 7-$ $2.0 \mu \mathrm{m}$, and showed a rapid corkscrew movement. The cells usually occurred singly or in pairs, but longer chains were sometimes observed. Pair of cells 

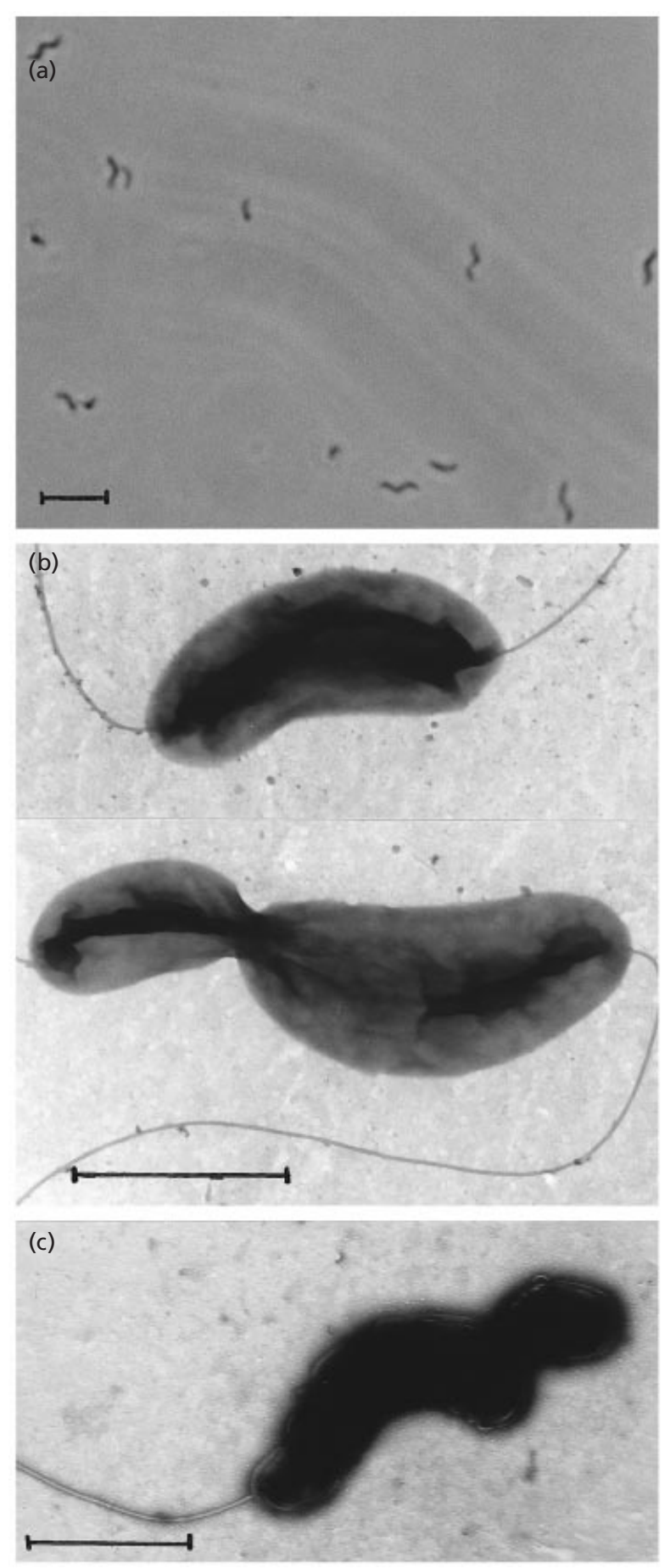

Fig. 1. Morphology of strain $\mathrm{N} 2460^{\top}$. (a) Phase-contrast micrograph of cells. Bar, $5 \mu \mathrm{m}$. (b)-(c) Transmission electron micrographs of negatively stained cells. Bars, $1 \mu \mathrm{m}$.

resembled the silhouette of a flying gull (Fig. 1a). Electron microscopy (Fig. 1b, c) revealed bipolar flagellation for some cells (a single flagellum at each end) and showed that the cells grew by budding. No spores were observed. The $\mathrm{KOH}$ test showed that the cells were Gram-negative.
Table 1. Phospholipid fatty acids of strain $\mathrm{N} 2460^{\top}$

In the designations of the fatty acids, the first number represents the number of carbon atoms and the second number represents number of double bonds. The $\omega$-number states the position of double bonds (as the number of $\mathrm{C}$-atoms from the carboxyl group); c, cis.

\begin{tabular}{|lc|}
\hline Fatty acid* & Abundance (\%) \\
\hline $\mathrm{C}_{14: 0}$ & $4 \cdot 7$ \\
$\mathrm{C}_{15: 0}$ & $0 \cdot 1$ \\
$\mathrm{C}_{16: 1 \omega 9}$ & $8 \cdot 9$ \\
$\mathrm{C}_{16: 1 \omega 7 \mathrm{c}}$ & $3 \cdot 3$ \\
$\mathrm{C}_{16: 1 \omega 5}$ & $0 \cdot 1$ \\
$\mathrm{C}_{16: 0}$ & $24 \cdot 4$ \\
$\mathrm{C}_{17: 1 \omega 8}$ & $0 \cdot 1$ \\
$\mathrm{C}_{17: 0}$ & $0 \cdot 3$ \\
$\mathrm{C}_{18: 1 \omega 7}$ & $49 \cdot 9$ \\
$\mathrm{C}_{18: 1}{ }^{*}$ & $0 \cdot 3$ \\
$\mathrm{C}_{18: 0}$ & $3 \cdot 4$ \\
Unidentified (sum) & $4 \cdot 5$ \\
\hline
\end{tabular}

* Position of double bond is uncertain (probably $\omega 5$ ).

\section{Enzyme assays}

The N2460 $0^{\mathrm{T}}$ cell extract had a specific activity of 2oxoglutarate dehydrogenase of $0.09 \mu \mathrm{mol} \mathrm{m^{-1 }} \mathrm{mg}$ protein $^{-1}$. No activity of carbon-monoxide dehydrogenase was detected. A cell extract from an SRB strain designated S2550 (DSM 12861) (S. Myhr, B. E. Thorbjørnsen and T. Torsvik, unpublished) showed a high activity of carbon-monoxide dehydrogenase under the same conditions.

\section{Phospholipid fatty acids}

Phospholipids of strain $\mathrm{N} 2460^{\mathrm{T}}$ contained $\mathrm{C}_{16}$ and $\mathrm{C}_{18}$ fatty acids as the major components (Table 1).

\section{DNA base composition}

The $\mathrm{G}+\mathrm{C}$ content of the DNA was $42 \cdot 6 \pm 0.4 \mathrm{~mol} \%$ (mean of three determinations).

\section{Phylogenetic analysis}

The 16S rRNA gene analysis showed that strain $\mathrm{N} 2460^{\mathrm{T}}$ belongs to the Bacteria. The closest relatives are 'Geovibrio ferrireducens', Deferribacter thermophilus and 'Flexistipes sinusarabici' (Fig. 2), with respective gene similarity values of $86.9,85.7$ and $85 \cdot 6 \%$

\section{Polyclonal antibodies}

The antiserum generated against strain $\mathrm{N} 2460^{\mathrm{T}}$ reacted strongly with its homologous strain (titre 100) in the FA-DAPI assay. The other control strains were negative. 


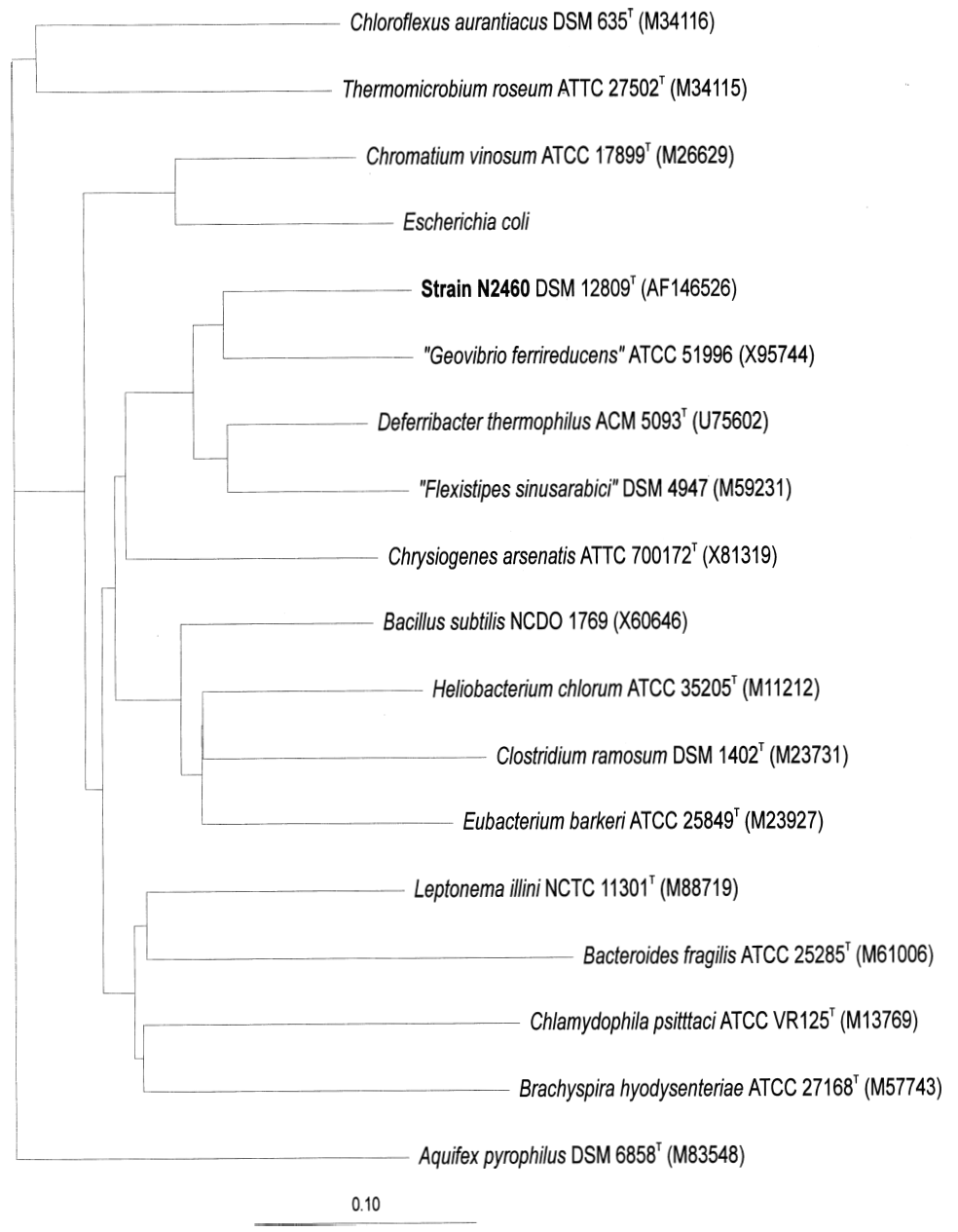

Fig. 2. Phylogenetic dendrogram based on $16 \mathrm{~S}$ rDNA data, showing the position of strain $\mathrm{N}_{2460^{\top}}$ among the Bacteria. Bar, 10 nucleotide substitutions per 100 nucleotides.

\section{Oligonucleotide probe}

The probe N2460A was specific for strain N2460 ${ }^{\mathrm{T}}$. The optimal conditions for whole-cell hybridization were $37^{\circ} \mathrm{C}$ and $20 \%$ formamide.

\section{DISCUSSION}

The isolated strain, $\mathrm{N} 2460^{\mathrm{T}}$, is a strictly anaerobic acetate specialist. The presence of a 2-oxoglutarate dehydrogenase activity indicates that acetate is oxidized via the citric acid cycle. In metabolic aspects, strain $\mathrm{N} 2460^{\mathrm{T}}$ is a nitrate-reducing analogue of the sulfate-reducing Desulfobacter. The Desulfobacter are, like strain $\mathrm{N} 2460^{\mathrm{T}}$, nutritionally specialized anaerobes with acetate as their characteristic substrate, though ethanol, lactate and hydrogen are used as electron donors by some species (Widdel \& Pfennig, 1981; Widdel, 1988). Desulfobacter species grow relatively fast on acetate and oxidize the substrate via a modified citric acid cycle. This is in contrast to other acetate-oxidizing SRB, which use the acetyl CoA pathway (with carbon-monoxide dehydrogenase as a key enzyme) and show much slower growth on the substrate (Widdel, 1988). The significantly shorter doubling time on acetate for strain $\mathrm{N} 2460^{\mathrm{T}}$ (ca. $8 \mathrm{~h}$ ) compared with Desulfobacter species (ca. 20 h) (Lien \& Beeder, 1997) can be explained by the fact that nitrate is a much better electron acceptor than sulfate.

Most obligately anaerobic NRB perform dissimilatory nitrate reduction to ammonia (DNRA), rather than denitrification to $\mathrm{N}_{2} / \mathrm{N}_{2} \mathrm{O}$ (Tiedje, 1988; Zumft, 1992). The detection of ammonia as the end product from nitrate reduction in strain $\mathrm{N} 2460^{\mathrm{T}}$ was therefore expected. The majority of DNRA bacteria gain energy only from the first reduction step (to nitrite). In these organisms, the further reduction of nitrite to ammonia probably serves as an electron sink for regeneration of oxidized co-enzymes or as a detoxification mechanism for nitrite (Tiedje, 1988). In some anaerobes, however, like Desulfovibrio desulfuricans (Steenkamp \& Peck, 1981), Desulfovibrio gigas (Barton et al., 1983), Campylobacter sputorum subsp. bubulus (de Vries et al., 1980), Wolinella succinogenes (Bokranz et al., 1983) and Sulfurospirillum deleyianum (Schumacher \& 
Table 2. Comparison of habitats and some characteristics of strain $N 2460^{\top}$ and the most-closely related bacteria

\begin{tabular}{|c|c|c|c|c|}
\hline Characteristic & Strain N2460 ${ }^{\mathrm{T}}$ & $\begin{array}{c}\text { 'Geovibrio ferrireducens' } \\
\text { ATCC } 51996\end{array}$ & $\begin{array}{c}\text { 'Flexistipes sinusarabici' } \\
\text { DSM } 4947\end{array}$ & 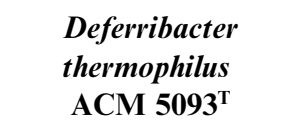 \\
\hline Habitat & $\begin{array}{l}\text { Oil reservoir } \\
\text { model column }\end{array}$ & $\begin{array}{c}\text { Surface sediment of } \\
\text { hydrocarbon-contaminated } \\
\text { ditch }\end{array}$ & $\begin{array}{l}\text { Atlantis II Deep } \\
\text { brines of the } \\
\text { Red Sea }\end{array}$ & $\begin{array}{l}\text { Produced water } \\
\text { from a North Sea } \\
\text { oil reservoir }\end{array}$ \\
\hline Gram reaction & Negative & Negative & Negative & Negative \\
\hline Morphology & Vibrio & Vibrio & Straight to bent rods & Straight to bent rods \\
\hline Metabolism & $\begin{array}{l}\text { Respiratory/ } \\
\text { fermentative }\end{array}$ & Respiratory & Fermentative & Respiratory \\
\hline Optimum temperature $\left({ }^{\circ} \mathrm{C}\right)$ & $35-37$ & 35 & $45-50$ & 60 \\
\hline Salinity range $(\% \mathrm{NaCl}, \mathrm{w} / \mathrm{v})$ & $0-6$ & $0-2$ & $3-10$ & $0-5$ \\
\hline DNA $\mathrm{G}+\mathrm{C}$ content $(\mathrm{mol} \%)$ & $42 \cdot 6$ & $42 \cdot 8$ & $38 \cdot 6$ & 34 \\
\hline \multicolumn{5}{|l|}{ Electron acceptors: } \\
\hline $\mathrm{NO}_{3}^{-}$ & + & - & NT & + \\
\hline $\mathrm{Fe}(\mathrm{III})$ & NT & + & NT & + \\
\hline $\operatorname{Mn}(I V)$ & NT & - & NT & + \\
\hline Sulfur & - & + & $(+)$ & - \\
\hline $\mathrm{O}_{2}$ tolerance & - & - & - & $(+)^{*}$ \\
\hline \multicolumn{5}{|l|}{ Electron donors: } \\
\hline Acetate & + & + & $(+)$ & + \\
\hline Lactate & - & + & - & + \\
\hline Propionate & - & + & NT & NT \\
\hline Fumarate & - & + & NT & - \\
\hline Proline & - & + & NT & NT \\
\hline Yeast extract & - & + & + & + \\
\hline $\mathrm{H}_{2}$ & - & + & - & + \\
\hline
\end{tabular}

* Grows in presence of $3 \% \mathrm{O}_{2}$, provided that $\mathrm{Fe}(\mathrm{III}), \mathrm{Mn}(\mathrm{IV})$ or nitrate is added as electron acceptor.

NT, Not tested.

Kroneck, 1992; Schumacher et al., 1992), the entire reduction process is coupled to electron transport phosphorylation. This may also be the case in strain $\mathrm{N} 2460^{\mathrm{T}}$. Since acetate is a non-fermentable substrate, it is unlikely that the nitrite-ammonia reduction step serves solely as an electron sink.

The 16S rDNA analysis showed that strain N2460 ${ }^{\mathrm{T}}$ belongs to the 'Flexistipes' group of the Bacteria. This is a recently discovered cluster of bacteria, consisting until now of only three genera and species: 'Flexistipes sinusarabici' (Fiala et al., 1990), 'Geovibrio ferrireducens' (Caccavo et al., 1996) and Deferribacter thermophilus (Greene et al., 1997). The fatty acid composition has only been investigated for 'Flexistipes sinusarabici' and strain $\mathrm{N} 2460^{\mathrm{T}}$. In both strains, $\mathrm{C}_{16}$ and $\mathrm{C}_{18}$ fatty acids are major components of the polar lipids. In strain $\mathrm{N} 2460^{\mathrm{T}}$, however, the $\mathrm{C}_{18}$ fatty acids are predominantly of the unsaturated form (one double bond), while the saturated form is dominant in 'Flexistipes sinusarabici'. 'Flexistipes sinusarabici' also differs from strain $\mathrm{N} 2460^{\mathrm{T}}$ in having iso-branched $\mathrm{C}_{14}$, anteiso-branched $\mathrm{C}_{15}$ and $\mathrm{C}_{17}$ fatty acids as important components. It should be noted, though, that all polar lipids were analysed for ' Flexistipes sinusarabici', while only the phospholipids (normally a major component of the polar lipids) were analysed for strain $\mathrm{N} 2460^{\mathrm{T}}$. Table 2 compares some characteristics of strain $\mathrm{N} 2460^{\mathrm{T}}$ and the three established species in the 'Flexistipes' cluster, as well as their habitats. It is evident that only two characteristics are shared by all four strains: they are obligate anaerobes and Gramnegative. Strain $\mathrm{N} 2460^{\mathrm{T}}$ and the closest relative (according to the $16 \mathrm{~S}$ rDNA data), 'Geovibrio ferrireducens', are the only mesophiles. The two strains have nearly identical $\mathrm{G}+\mathrm{C}$ values and both are vibrios. Strain $\mathrm{N} 2460^{\mathrm{T}}$ differs, however, in showing bipolar flagellation and a budding form of growth. Major differences in salinity range and spectra of electron donors and acceptors utilized also clearly distinguish the two strains. 'Geovibrio ferrireducens' is an ironreducing, freshwater bacterium and exhibits a much broader substrate spectrum than strain $\mathrm{N} 2460^{\mathrm{T}}$. Deferribacter thermophilus reduces nitrate but differs from strain $\mathrm{N} 2460^{\mathrm{T}}$ in most of the other characteristics listed, except for salinity range. 'Flexistipes sinusarabici' is a fermentative, halophilic and slightly thermophilic bacterium that shares few phenotypic traits with strain $\mathrm{N} 2460^{\mathrm{T}}$.

Considering the facts that two of the closest relatives of strain $\mathrm{N} 2460^{\mathrm{T}}$ are iron reducers and that several other 
NRB also perform iron reduction (Sørensen, 1982; Jones et al., 1983, 1984; Lovley \& Phillips, 1988), we wanted to test strain $\mathrm{N} 2460^{\mathrm{T}}$ for this trait. As mentioned, however, ferric pyrophosphate reacted chemically with sulfide in the medium, raising the redox potential and causing growth inhibition of the bacterium. The chemical reaction between ferric iron and sulfide, leading to sulfur and $\mathrm{FeS}$, has been described previously (Widdel, 1988). In spite of this chemical reaction, it should be possible for sulfide and ferric iron to co-exist in a natural gradient/biofilm when complex microbial populations are involved. Ferrous iron can be reoxidized to the ferric state by both aerobic (Wood, 1988; Emerson \& Revsbeck, 1994a, b) and anaerobic (Straub et al., 1996; Hafenbradl et al., 1996) bacteria and hydrogen sulfide can be supplied continuously from SRB in the layer beneath. Accordingly, our results do not exclude the existence of a niche for iron reduction by strain N $2460^{\mathrm{T}}$ in the environment.

The oil reservoir model column was initially inoculated with enrichment cultures from several different sources. NRB were selectively enriched only from the nitrate bioreactor, which is an analogue system to the model column, containing oil, sulfide, seawater and externally added nitrate. It therefore seemed likely that the bioreactor was the source of strain $\mathrm{N} 2460^{\mathrm{T}}$. Yet, efforts to isolate the strain from the bioreactor 3 years after the first enrichment failed (unpublished data). This may have been due to operating problems and reinoculation of the reactor during this period. It is, however, also possible that strain $\mathrm{N} 2460^{\mathrm{T}}$ originated from one of the other inocula, as acetate is a common fermentation product in almost any anoxic environment (Gottschalk, 1986). The most likely inocula would be the marine/brackish ones that were used for anaerobic enrichments, produced water (sampled from mesophilic parts of the pipelines) and ballast/process water from the Mongstad biological treatment plant. The polyclonal antibodies and oligonucleotide probe that we developed can be used for screening of environmental samples for strain $\mathrm{N} 2460^{\mathrm{T}}$.

Based on the 16S rDNA analysis as the main criterion, together with the phenotypic differences between strain $\mathrm{N} 2460^{\mathrm{T}}$ and 'Geovibrio ferrireducens' (as well as the other relatives), we suggest that strain $\mathrm{N} 2460^{\mathrm{T}}$ represents the type strain of a new genus and species, Denitrovibrio acetiphilus.

\section{Description of Denitrovibrio gen. nov.}

Denitrovibrio (De.ni.tro.vi'bri.o. L. pref. de from; M.L. n. nitrum nitrogen; L. v. vibrare vibrate; M.L. n. vibrio that which vibrates; Denitrovibrio a vibrio that reduces nitrate).

Cells are Gram-negative and vibrio-shaped, occurring singly, in pairs or in chains. No spores are formed. Strictly anaerobic, heterotrophic growth with nitrate as electron acceptor. Phylogenetically, the genus belongs to the Bacteria, clustering together with the genera 'Flexistipes', 'Geovibrio' and Deferribacter.

\section{Description of Denitrovibrio acetiphilus sp. nov.}

Denitrovibrio acetiphilus (a.ce.ti'phi.lus. L. n. acetum vinegar; M.L. n. acidum aceticum acetic acid; Gr. v. philein to like, love; M.L. adj. acetiphilus loving or requiring acetate).

Cells are $0.5-0.7 \times 1.7-2.0 \mu \mathrm{m}$ and motile by bipolar flagella. Growth occurs between 4 and $40{ }^{\circ} \mathrm{C}$ (optimum at $35-37^{\circ} \mathrm{C}$ ), with $\mathrm{NaCl}$ concentrations ranging from 0 to $6 \%$ (optimum at $2-4 \%$ ) and at $\mathrm{pH} 6 \cdot 5-8 \cdot 6$. Acetate is the only electron donor utilized with nitrate as electron acceptor. Nitrate is reduced to ammonia, with nitrite as an intermediate. Sulfate, thiosulfate and sulfur are not used as alternative electron acceptors. Fumarate can be fermented, while pyruvate is not utilized. Vitamins are required. Phospholipids contain $\mathrm{C}_{16: 0}, \mathrm{C}_{16: 1 \omega 9}$ and $\mathrm{C}_{18: 1 \omega 7}$ fatty acids as the principal compounds. The DNA G $+\mathrm{C}$ content is $42.6 \mathrm{~mol} \%$.

The type strain, Denitrovibrio acetiphilus $\mathrm{N} 2460^{\mathrm{T}}$, was isolated from an $\mathrm{H}_{2} \mathrm{~S}$-producing oil reservoir model column flooded by nitrate-enriched synthetic seawater. Strain N2460 ${ }^{\mathrm{T}}$ has been deposited at the DSMZ (DSM $\left.12809^{\mathrm{T}}\right)$.

\section{ACKNOWLEDGEMENTS}

We are grateful to Bente-Lise Polden Lillebø for operating the model column and to Bente Edtem Thorbjørnsen for preparation of anoxic substrates. We thank Jon Hovland for offering a fatty acid analysis at Norsk Hydro Research Centre, Mona Galteland for great practical work and Erling Odden and Asa Frostegård for interpretation of the GC/MS data. Torleiv Lien is thanked for kindly supplying methods and equipment for enzyme assays and Irene Heggstad for development of electron micrographs. Finally, we thank Jostein Goksøyr for valuable comments on the manuscript. This work was financed by Statoil and Norsk Hydro.

\section{REFERENCES}

Amann, R. I. (1995). In situ identification of micro-organisms by whole cell hybridization with rRNA-targeted nucleic acid probes. Mol Microb Ecol 3.3.6, 1-15.

Barton, L. L., LeGall, J., Odom, J. M. \& Peck, H. D., Jr (1983). Energy coupling to nitrite respiration in the sulfate-reducing bacterium Desulfovibrio gigas. J Bacteriol 153, 867-871.

Beeder, J. (1996). Sulfate-reducing prokaryotes from North Sea oil reservoirs; organisms, distribution and origin. $\mathrm{PhD}$ thesis, University of Bergen, Norway.

Beeder, J., Nilsen, R. K., Torsvik, T. \& Lien, T. (1994). Archaeoglobus fulgidus isolated from hot North Sea oil field waters. Appl Environ Microbiol 60, 1227-1231.

Bokranz, M., Katz, J., Schrøder, I., Roberton, A. M. \& Krøger, A. (1983). Energy metabolism and biosynthesis of Vibrio succinogenes growing with nitrate or nitrite as terminal electron acceptor. Arch Microbiol 135, 36-41.

Bradford, M. M. (1976). A rapid and sensitive method for the quantitation of microgram quantities of protein utilizing the principle of protein-dye binding. Anal Biochem 72, 248-254. 
Buck, J. D. (1982). Nonstaining $(\mathrm{KOH})$ method of gram reactions of marine bacteria. Appl Environ Microbiol 44, 992-993.

Caccavo, F., Jr, Coates, J. D., Rosello-Mora, R. A., Ludwig, W., Schleifer, K. H., Lovley, D. R. \& McInerney, M. J. (1996). Geovibrio ferrireducens, a phylogenetically distinct dissimilatory Fe(III)reducing bacterium. Arch Microbiol 165, 370-376.

Cashion, P., Holder-Franklin, M. A., McCully, J. \& Franklin, M. (1977). A rapid method for the base ratio determination of bacterial DNA. Anal Biochem 81, 461-466.

Christensen, B., Torsvik, T. \& Lien, T. (1992). Immunomagnetically captured thermophilic sulfate-reducing bacteria from North Sea oil field waters. Appl Environ Microbiol 58, $1244-1248$.

Emerson, D. \& Revsbeck, N. P. (1994a). Investigation of an ironoxidizing microbial mat community located near Aarhus, Denmark: field studies. Appl Environ Microbiol 60, 4022-4031.

Emerson, D. \& Revsbeck, N. P. (1994b). Investigation of an ironoxidizing microbial mat community located near Aarhus, Denmark: laboratory studies. Appl Environ Microbiol 60, 4032-4038.

Felsenstein, J. (1993). PHYLIP (phylogeny inference package), version 3.5.1. Department of Genetics, University of Washington, Seattle, WA, USA.

Fiala, G., Woese, C. R., Langworthy, T. A. \& Stetter, K. O. (1990). Flexistipes sinusarabici, a novel genus and species of eubacteria occurring in the Atlantis II Deep brines of the Red Sea. Arch Microbiol 154, 120-126.

Frostegård, Å., Tunlid, A. \& Bååth, E. (1993). Phospholipid fattyacid composition, biomass and activity of microbial communities from two soil types experimentally exposed to different heavy metals. Appl Environ Microbiol 59, 3605-3617.

Gottschalk, G. (1986). Bacterial fermentations. In Bacterial Metabolism, 2nd edn, pp. 208-282. New York: Springer.

Greene, A. C., Patel, B. K. C. \& Sheehy, A. J. (1997). Deferribacter thermophilus gen. nov., sp. nov., a novel thermophilic manganese- and iron-reducing bacterium isolated from a petroleum reservoir. Int J Syst Bacteriol 47, 505-509.

Hafenbradl, D., Keller, M., Dirmeier, R., Rachel, R., Rossnagel, P., Burggraf, S., Huber, H. \& Stetter, K. O. (1996). Ferroglobus placidus gen. nov., sp. nov., a novel hyperthermophilic archaeum that oxidizes $\mathrm{Fe}^{2+}$ at neutral $\mathrm{pH}$ under anoxic conditions. Arch Microbiol 166, 308-314.

Hamilton, W. A. (1985). Sulphate-reducing bacteria and anaerobic corrosion. Annu Rev Microbiol 39, 195-217.

Herbert, B. N. (1987). Reservoir souring. In Microbial Problems in the Offshore Oil Industry, pp. 63-71. Edited by E. C. Hill, J. L. Shennan \& R. J. Watkinson. Chichester: Wiley.

Hoff, K. A. (1988). Rapid and simple method for double staining of bacteria with 4,6-diamidino-2-phenylidole and fluorescein isothiocyanate-labelled antibodies. Appl Environ Microbiol 54, 2949-2952.

Jones, J. G., Gardener, S. \& Simon, B. M. (1983). Bacterial reduction of ferric iron in a stratified eutrophic lake. $J$ Gen Microbiol 129, 131-139.

Jones, J. G., Gardener, S. \& Simon, B. M. (1984). Reduction of ferric iron by heterotrophic bacteria in lake sediments. $J$ Gen Microbiol 130, 45-51.

Jukes, T. H. \& Cantor, C. R. (1969). Evolution of protein molecules. In Mammalian Protein Metabolism, pp. 21-132. Edited by H. N. Munro. New York: Academic Press.

Lien, T. \& Beeder, J. (1997). Desulfobacter vibrioformis sp. nov., a sulfate reducer from a water-oil separation system. Int $J$ Syst Bacteriol 47, 1124-1128.

Ljungdahl, L. G. \& Wiegel, J. (1986). Working with anaerobic bacteria. In Manual of Industrial Microbiology, pp. 84-96. Edited by A. L. Demain \& N. A. Solomon. Washington, DC: American Society for Microbiology.

Lovley, D. R. \& Phillips, E. J. P. (1988). Novel mode of microbial energy metabolism: organic carbon oxidation coupled to dissimilatory reduction of iron or manganese. Appl Environ Microbiol 54, 1472-1480.

Maidak, B. L., Olsen, G. J., Larsen, N., Overbeek, R., McCaughey, M. J. \& Woese, C. R. (1996). The Ribosomal Database Project (RDP). Nucleic Acids Res 24, 82-85.

Mesbah, M., Premachandran, U. \& Whitman, W. B. (1989). Precise measurement of the $\mathrm{G}+\mathrm{C}$ content of deoxyribonucleic acid by high-performance liquid chromatography. Int $J$ Syst Bacteriol 39, 159-167.

Odden, E. (1998). Analyse av fosfolipid fettsyrer som biomarkører for modellering av det mikrobielle samfunn i biologiske renseprosesser. MSc thesis, Høgskolen i Telemark, Norway.

Pfennig, N. (1978). Rhodocyclus purpureus gen. nov. and sp. nov., a ring-shaped, vitamin $\mathrm{B}_{12}$-requiring member of the family Rhodospillaceae. Int J Syst Bacteriol 28, 283-288.

Rainey, F. A., Ward-Rainey, N., Kroppenstedt, R. M. \& Stackebrandt, E. (1996). The genus Nocardiopsis represents a phylogenetically coherent taxon and a distinct actinomycete lineage: proposal of Nocardiopsaceae fam. nov. Int J Syst Bacteriol 46, 1088-1092.

Reinsel, M. A., Sears, J. T., Stewart, P. S. \& Mclnerney, M. J. (1996). Control of microbial souring by nitrate, nitrite or glutaraldehyde injection in a sandstone column. J Ind Microbiol 17, 128-136.

Saitou, N. \& Nei, M. (1987). The neighbor-joining method: a new method for reconstructing phylogenetic trees. Mol Biol Evol 4, 406-425.

Schumacher, W. \& Kroneck, P. M. H. (1992). Anaerobic energy metabolism of the sulfur-reducing bacterium 'Spirillum' 5175 during dissimilatory nitrate reduction to ammonia. Arch Microbiol 157, 464-470.

Schumacher, W., Kroneck, P. M. H. \& Pfennig, N. (1992). Comparative systematic study on 'Spirillum' 5175, Campylobacter and Wolinella species: description of 'Spirillum' 5175 as Sulfurospirillum deleyianum gen. nov., spec. nov. Arch Microbiol 158, 287-293.

Solorzano, L. (1969). Determination of ammonia in natural waters by the phenol/hypochlorite method. Limnol Oceanogr 14, 799-801.

Sørensen, J. (1982). Reduction of ferric iron in anaerobic, marine sediment and interaction with reduction of nitrate and sulfate. Appl Environ Microbiol 43, 319-324.

Steenkamp, D. J. \& Peck, H. D., Jr (1981). Proton translocation associated with nitrite respiration in Desulfovibrio desulfuricans. $J$ Biol Chem 256, 5450-5458.

Straub, K. L., Benz, M., Schink, B. \& Widdel, F. (1996). Anaerobic nitrate-dependent microbial oxidation of ferrous iron. Appl Environ Microbiol 62, 1458-1460.

Tiedje, J. M. (1988). Ecology of denitrification and dissimilatory nitrate reduction to ammonium. In Biology of Anaerobic Microorganisms, pp. 179-244. Edited by A. J. B. Zehnder. New York: Wiley.

de Vries, W., Niekus, H. G. D., Boellaard, M. \& Stouthamer, A. H. 
(1980). Growth yields and energy generation by Campylobacter sputorum subspecies bubulus during growth in continuous culture with different hydrogen acceptors. Arch Microbiol 124, 221-227.

Widdel, F. (1988). Microbiology and ecology of sulfate- and sulfur-reducing bacteria. In Biology of Anaerobic Microorganisms, pp. 469-585. Edited by A. J. B. Zehnder. New York: Wiley.

Widdel, F. \& Pfennig, N. (1981). Studies on dissimilatory sulfatereducing bacteria that decompose fatty acids. I. Isolation of new sulfate-reducing bacteria enriched with acetate from saline environments. Description of Desulfobacter postgatei gen. nov., sp. nov. Arch Microbiol 129, 395-400.

Widdel, F., Kohring, G. W. \& Mayer, F. (1983). Studies of dissimilatory sulfate-reducing bacteria that decompose fatty acids. III. Characterization of the filamentous gliding Desulfonema limicola gen. nov. and sp. nov. and Desulfonema magnum sp. nov. Arch Microbiol 134, 286-294.

Wood, P. M. (1988). Chemolithotrophy. In Bacterial Energy Transduction, pp. 183-230. Edited by C. Anthony. London: Academic Press.

Zeikus, J. G., Fuchs, G., Kenealy, W. \& Thauer, R. K. (1977). Oxidoreductases involved in cell carbon synthesis of Methanobacterium thermoautotrophicum. J Bacteriol 132, 604-613.

Zumft, W. G. (1992). The denitrifying bacteria. In The Prokaryotes, 2nd edn, pp. 554-582. Edited by A. Balows, H. G. Truper, M. Dworkin, W. Harder \& K.-H. Schleifer. New York: Springer. 